\section{Indian patent law will protect crops 'unless injurious to health'}

\section{New Delhi}

The Indian government has presented a bill to parliament proposing a law giving patent protection to new crop varieties for 15 years, but allowing patent applications to be rejected for varieties for which the commercial exploitation "may be injurious to health".

The clause allowing rejection is seen as a bid to ban both the import of genetically modified foods and the cultivation of transgenic plants where questions remain about their safety for human health or the environment.

To be eligible for patent protection, a variety "must be new, distinct, uniform and stable". But those containing "harmful genes or gene sequences like the terminator gene" will be refused registration.

Judgements about both patentability and safety will be made by a National Plant Protection Authority that will be created under the act to implement all provisions of the legislation, including testing. It will use existing lab facilities of the Indian Council of Agricultural Research until it sets up its own.

The council says the safety criteria are listed in the recombinant-DNA research guidelines issued by the Department of Biotechnology.

The legislation will not affect the right of farmers to save, exchange or sell produce of the protected variety, or the right of researchers to have access for research. But a National Gene Fund will pass some of the sale proceeds of new varieties to the village communities that preserved the plant genetic resources.

The government claims that the legislation, by ensuring a return for investment, will "facilitate the growth of the seed industry through domestic and foreign investment". K. S. Jayaraman

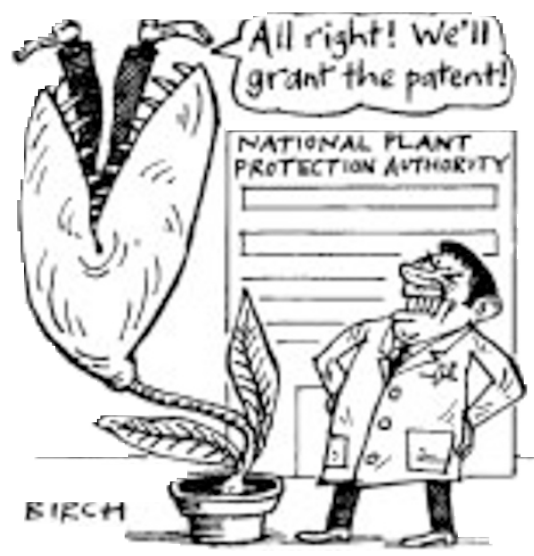

\title{
EU candidate states impress with Framework proposals
}

London

Cyprus, Estonia, Lithuania and Slovenia achieved the highest success rate of the 11 'candidate' countries seeking membership of the European Union in the first round of funding applications for the EU's fifth Framework research programme (FP5). Their achievement emerged from an analysis presented last week to a meeting of the council of research ministers in Brussels.

The European Commission was reporting on the progress of candidate countries within FP5. Research is the first sector in which candidate countries fully share the implementation of EU policy under similar conditions to member states. The commission described the results as "encouraging".

Around 12,000 proposals were made to FP5 programmes, with 29 per cent being approved for possible funding. Of the approved applicants, four per cent were from candidate countries, and, within the thematic programmes, candidate countries participated in a quarter of the proposals.

Poland, Hungary and the Czech Republic made most proposals (see graph), and proposers are mainly from the public sector. Romania performed surprisingly poorly, given its high level of participation in earlier programmes, and the reasons for this are to be investigated further.

At the same meeting, the council of ministers agreed on the timetable for the sixth Framework programme and on funding the dismantling of its nuclear installations. It also adopted a resolution on a European strategy for space, and is considering working with the

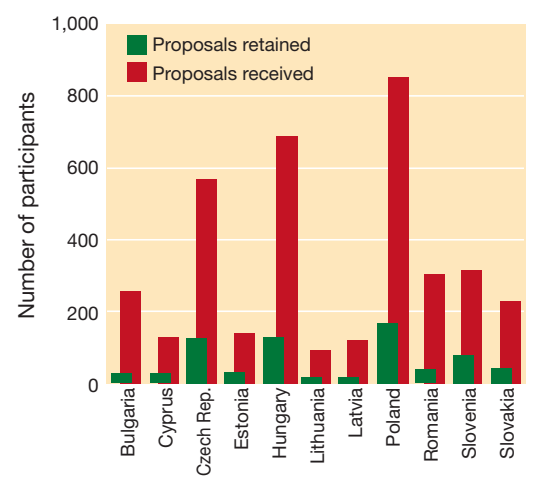

How candidate countries scored with their Framework funding proposals.

European Space Agency on projects such as Galileo and Ariane. There was also agreement to create a reserve fund to allow swift action on new research priorities. In the past, the commission has struggled to find enough flexibility in research funds to provide for areas such as AIDS and BSE.

The topic of women in science also featured prominently at the meeting, where the commission's expert report on the issue in member states was presented (see Nature 402,337 ; 1999). Some member states called for "practical action", said a spokesperson.

The German delegation suggested that research organizations that do particularly well in recruiting women should receive a financial bonus. Such a scheme has been successful in Germany, and this proposal could well be taken forward at a conference in April and become a theme of the next meeting of EU research ministers in June. Natasha Loder

\section{US close to funding stem-cell work}

\section{Washington}

The US National Institutes of Health (NIH) could provide funding for research on human embryonic stem cells as early as the spring if new guidelines, published by the $\mathrm{NIH}$ last week after widespread public consultation, are formally approved.

The guidelines try to distinguish between the derivation of the cells from embryos, which the US government is forbidden by Congress from funding, and research on the cells once they have been isolated, which can be funded (see Nature 397, 185; 1999). Under the proposed rules, stem cells can be taken only from spare frozen embryos after the conclusion of in vitro fertilization attempts.

"This is a way to ensure a separation between the creation of the embryo and the decision to donate to research," says Lana Skirboll, director of science policy at the NIH. Physicians involved with in vitro fertilization will not be eligible for NIH funds for research on cells they derive themselves.

The rules are "quite reasonable", according to James Thomson, a researcher at the University of Wisconsin-Madison who, with private funding, first cultured pluripotent cells from embryos last November.

But the proposed informed-consent form may be sufficiently different from the one used by Thomson that it may not allow his cells to be used, he says. If necessary, his laboratory will culture another stem-cell line under the new guidelines. The guidelines are available at http://www.nih.gov/news/ stemcell/draftguidelines.htm. Paul Smaglik 